\title{
NEW BUSINESS MODEL IN THE GROWING E-SPORTS INDUSTRY *
}

\author{
Anita Radman Peša ${ }^{1}$, Dijana Čičin-Šain ${ }^{2}$ \& Toni Blažević ${ }^{3}$
}

UDC /UDK: 004.928+796/799]:339.13.021

JEL classification / JEL klasifikacija: L82

DOI: https://doi.org/10.22598/pi-be/2017.11.2.121

Review / Pregledni rad

Received / Primljeno: September, 28, 2017 / 28. rujna 2017.

Accepted for publishing / Prihvaćeno za tisak: November 27, 2017 / 27. studenoga 2017.

\section{Summary}

E-sports - competition based playing of video games is becoming a growing industry and an increasingly frequent subject of various international research. The purpose of this analysis is to design a new, innovative business model in the e-sports industry, which it will be possible to apply in the form of a significant business opportunity. The main goals of this paper include determining the key components of the success of e-sports in the growing video game industry and presenting some innovative ways of using them in the form of new business opportunities. By observing the concept of e-sports through several components, it is possible to analyze their profitability and the possibility of profiting primarily from the entrepreneurship perspective. Furthermore, the paper determines the segmentation of the e-sports target market and compares it to the traditional sports markets, since these two concepts, according to various authors, should be viewed separately. model.

Key words: e-sports industry, e-sports market, market segmentation, business

\footnotetext{
The paper was presented at the 2nd International Conference "Business \& Entrepreneurial Economics -BEE2017" which was held in Brijuni from 24 to 26 May 2017 (www.bee-conference.com)

1 Anita Radman Peša, Ph.D., Assistant Professor, University of Zadar, Department of Economics, E-mail: apesa@unizd.hr

2 Dijana Čičin-Šain, MA, Senior Lecturer, University of Zadar, Department of Economics, E-mail: dcsain@ unizd.hr

3 Toni Blažević, bacc. oec., Student at University of Zadar, Department of Economics, E-mail: tblazevic@ student.unizd.hr
} 


\section{INTRODUCTION}

With developments of technology, especially different kinds of media, the use of video games is also increasing globally. With a growth rate between 10 and 15 per cent per year over a 25 -year period, velocity is high (Zackariasson \& Wilson, 2010). In turn, the economic value of video games has shifted from a niche industry to a blockbuster business. Today, more Americans play video games than go to the movies (NPD Group, 2009), and in 2012, global revenues were an estimated $\$ 67$ billion for console and portable hardware and software (Marchand \& Hennig-Thurau, 2013). Different groups of people in all parts of the world with suitable conditions ${ }^{4}$, enjoy one of the forms of this type of entertainment on a daily basis. There are many different forms that could be analyzed, but the focus of this analysis is one of the fastest growing industries in the world - the e-sports industry.

We define e-sports (electronic sports) as a form of sports where the primary aspects of the sport are facilitated by electronic systems; the input of players and teams as well as the output of the e-sports system are mediated by human-computer interfaces. (Hamari \& Sjöblom, 2017). In simpler words, e-sports is a form of video gaming where individual users, both players and teams (when a team game is taking place) compete with each other in playing digital video games on computers using Internet or LAN. E-sports is oriented towards competitive video gaming that is mostly coordinated by different leagues, scales and tournaments, where players join teams and other "sports" organizations sponsored by various companies.

Such a definition and the related explanation of e-sports can hardly illustrate the main success factors of this phenomenon. The reason for this lies in the difference between the video games we play against the computer itself $f^{5}$ and those that have the potential to be categorized as e-sports. The latter video games have to be played online or through the connection to two consoles, computers or similar technologies. With that in mind, e-sports allows for various forms of interaction between video games consumers before, during and after the gaming process is concluded. Thanks to this opportunity for consumer interaction, an analysis of the e-sports phenomenon can be undertaken by separating the processes of playing, socializing, and even watching others play. This allows for the contribution of the players to e-sports to be analyzed individually, but also in larger groups with a synergistic effect. This stated division is an empirical and intuitive one, and it serves only as a starting point for exploring potentially profitable investments in the e-sports phenomenon within the new market. The following research questions will contribute to the analysis: What are the growth and success factors of the e-sports industry? Who are the consumers and who are the other entities within the e-sports industry? What are the needs of potential consumers? Which business plan best meets the needs of our target market with its possibility of profitability?

\footnotetext{
4 Conditons include: a personal computer or laptop, a smartphone, different consoles, or access to an Internet connection.

5 The player tries to beat the computer, commonly known as the AI - Artificial Intelligence; games often allow the player to choose between the difficulty settings, from the easiest to the more difficult.
} 


\section{METHODOLOGY}

The aim of this paper is to highlight e-sports as an opportunity to join the global trend and all its accompanying privileges. This will be done in the form of a business plan that is applicable both globally and locally, or within a still unexplored online video game market, commonly referred to as e-sports, on the territory of Croatia. In this regard, the main goal will be to compare the e-sports industry with the already established traditional sports industry, together with its accompanying cultural and consumer segment. Furthermore, each of the components of e-sports, which greatly contributes to the success of this trend, will be segmented, highlighted and analyzed separately. The infrastructural and other prerequisites for the success of one or all of the components of e-sport will be defined and proposed within the business model, and then, by using an inductive method, a conclusion about the feasibility of investing in the analyzed components, or more precisely in the success rate of different factors, will be made.

\section{E-SPORTS INDUSTRY}

The history of video game development as an industry and a cultural movement is largely addressed in literature, but not all of the sources agree about the reasons for the constant growth and development of the industry. Some authors find a reason for that in Internet expansion (at that time: world wide web), while the others see it in the rapid growth of 1980-s arcade games (Borowy, 2008). In order to promote the gaming culture, the owners of arcade games started organizing various tournaments, as was the case with traditional sports in its beginnings. Similar to traditional sports, the initially unstructured competition began to change into structured tournaments, involving sponsors, viewers and some media attention.

The next big leap in the development of the e-sports industry occurred in the 1990s with the emergence of gaming consoles and the release of a large number of different video games on the market. By developing the technology, but also the gaming culture, a change occurred in the way that these video games were played. Players can now enjoy games at home, but also in Internet cafes, and by doing so they increasingly participate in forming their own experience.

Nowadays, more and more people understand e-sports as a synonym for big public gaming events, where thousands of people play, and millions watch them through various online streams (Borowy, 2008).

In order to be able to divide e-sports into its component parts, each of them representing a separate "product", it is first necessary to determine the profile of a typical consumer, more precisely to perform a segmentation of the market.

\subsection{Market segmentation of e-sports industry}

The most attractive thing for e-Sports players is actually the multiplayer nature of playing and social interactions between the players in a real or virtual environment, not 
the playing itself (Martončik, 2015). After that comes fun, and only after that, winning. Such a priority system can be compared to Maslow's hierarchy of needs, indicating that the majority or almost the majority of consumers within the eSports industry strive to meet the (social) need of belonging to a group, which within eSports can be satisfied through communication with or belonging to a team with other players of similar desires and needs. By further reviewing available literature, we can find data that supports the merging of online and offline realities, at least in the context of certain genres of video games, such as the increasingly popular MMORPGs ${ }^{6}$. For example, a study was conducted which concludes that on - and offline are inexorably linked through the social organizational demands of online gaming and that an online game puts people together and gives them a shared purpose, offering the structural foundation for relationships (Eklund, 2014).

What motivates e-sports gamers the most? A research was conducted which presented three main components (of motivation): achievement component, social component and immersion component (Yee, 2006). With that in mind, a conclusion can be made about at least three different approaches to marketing the e-sports industry: the achievement component is based on the competitive, sport oriented consumerist spirit. The second approach again affects the human need for socialization and social networking. The last approach is based on enjoyment, or more precisely the ability of the player to "immerse" himself/herself into the content of the game or its individual parts. Furthermore, statistics exist regarding a typical online games consumer, who is on average 26 years old, and typically spends $22 \mathrm{~h}$ per week in these environments (Yee, 2006). However, recent research shifts the average age of players to 35 years, while showing potentially surprising data regarding the proportion of sexes involved in video game consumption: $56 \%$ of men and $44 \%$ of women (ESA, 2015).

However, as noted above, playing video games is not the only way to consume them. In other words, e-sports includes far more than the players themselves. Some motivation components can be achieved even while observing others while they play. Hundreds of millions of users choose to spend their time watching others play video games through live internet broadcasts, referred to as streams, on services such as Twitch (Hamari \& Sjöblom, 2016). What motivates these users to spend their time watching others play video games? Hamari \& Sjöblom also showed that when examining the results more closely, tension release was seen as being the strongest positive predictor of how many hours users watched streams. (ibid). The latter statement will play a major role in deriving a conclusion about the reasons and motivation for the inclusion of video games, specifically those within the e-sports industry, into the global video streaming trend.

\subsection{Success factors of e-sports industry}

TwitchTV is an internet platform used for transmitting and watching video streams live. Currently it gathers a large number of players and consumers which are not necessarily playing the games, but are watching others play, and they mutually com-

\footnotetext{
6 Massive Multiplayer Online Role Playing Game - a massive online game with multiple players within which each player assumes an individual role, each different while at the same time complementary.
} 
municate. Amazon said on Monday it would pay $\$ 970$ million in cash for Twitch, a live video-game-streaming site (Kim, 2014). That statement turned out to be correct, as Twitch Interactive is now a subsidiary of Amazon.com. TwitchTV shows over 9.7 million different viewers per day, with around 2 million different players streaming their games over Twitch on a monthly basis, and with an average 106 minutes per day for each individual viewer (Twitch.tv, 2017).

E-sports tournaments and events form part of TwitchTV's contents (first streamed live, and then searchable similarly to the Youtube platform), live players directly stream their games, and various related shows dedicated to gaming and the players themselves are aired as well. Competitions (tournaments, cups, leagues) are frequent and are always held in a different city on the continental and global level, meaning that they need to be organized, live broadcasts have to be provided as well as commentators and presenters. As of recent, ESPN is broadcasting e-sports competitions and relevant news about changes in e-sports games and related teams (ESPN, 2016).

While the increase in the number of video game viewers over the TwitchTV platform is certainly an interesting trend to be observed from the entertainment industry's perspective, in recent times it has become an even bigger factor for video game creators and distributors. A positive correlation was observed between the increase in the number of viewers and the sale of video games, which recently attracted the attention of the federal regulatory agencies. A study released by live streaming company Twitch attributed 25 percent of sales of releases like the fighting simulator "Punch Club" and the kill-or-be-killed multiplayer game "The Culling" to those games being played on Twitch. The study found that viewers were more likely to buy a game within 24 hours of watching a stream of the game in action (Lang, 2016).

One of the success factors of e-sports is the existence of gaming teams or clans (names vary from game to game). Various companies sponsor these teams. The Cloud 9 organization, which has its competition team in 10 e-sports games events, sponsors or is partner with 13 major companies (including Ax, Logitech, Intel, TwitchTv, etc.). The existence of these teams and their players is certainly one of the key factors for the success of the e-sports industry. By acting in the direction of mutual and constant training in the game, they engage in strong interaction with other, less successful e-sports consumers - viewers and recreational players. These players often leave one team and join another, which means large cash transfers and the incidental promotion of e-sports content. The professional gamers themselves also earn money while playing for their team. An example of a successful professional gamer in Croatia is the 18-years-old Luka Perković, who has in his two years as a professional player earned about 41,000 US dollars from awards in sports competitions. Another player from Bosnia and Herzegovina can also be used as an example earning just over 92,000 US dollars (Esportsearnings, 2017). It is important to remember that these two players, apart from participating in team professional competitions, also streamline their content through the TwitchTv platform, which allows them to additionally profit from subscribers to their channel, as well as through donations from fans. Such players gather large groups of fans and proponents of the e-sports culture, but someone first needs to recognize their potential and provide them with the necessary incentives, a place and conditions for training and 
constant improvement. Basically they need to be sponsored, and helped in the process of building a brand.

Given that such a system of organizing competitions and the viewership strongly resembles sports, as well as the fact that the name of the e-sports industry contains the word sport itself, it is necessary to state this as another success factor.

\subsection{Comparison of e-sports and sport industries}

With its rapid growth, the e-sports industry has attracted the attention of a large number of young people, and with its approach it represents a challenge for modern sports. Gaming, unlike organized sports, is not so well accepted by some parents and other adults, being considered to be a waste of time and energy, all resources that could be used in more useful ways. Furthermore, the concept of gaming still has negative connotations with some people, similar to addiction, aggression and social isolation. Notwithstanding, competitive gaming is in full swing. Many players want to measure and compare their abilities with and against other players. The fact that these competitions are considered sport-like forms, as 'sports', explains the label 'Electronic Sport' or 'eSport' (Jonasson \& Thiborg, 2010). Perhaps this could be viewed as an attempt to legitimize e-sports for a wider target audience.

There have been such attempts to legitimize e-sports. Specifically, Guttman has conceptualized seven distinguishing characteristics of modern sport which he uses to identify and describe sport through history: Secularism/Secularization, Equality, Specialization, Bureaucratization, Rationalization, Quantification, Obsession with/the quest for Records (Jonasson \& Thiborg, 2010). For something to be considered a sport, it must meet all seven criteria. In the case of the e-sports industry it can be argued that the bureaucratization is not entirely grounded, at least not in the form of a central controlling body. However, the rules are clear and constant for all players and most of the competitions. The other criteria are all met, and the emphasis should be placed on rationalization. Rationalization implies a constant improvement of technique and knowledge of sports, and continuous progress. This segment within the e-sports industry is particularly supported by various content related to games that fall under the term e-sports, including tutorials, instructions and tips how to play. Authors of these materials/contents are all e-sports industry players: from game makers, through professional players, to recreational consumers and e-sports audiences. This brings about a twofold effect: the level of the quality of gaming activities and its understanding increases, and even more importantly, a wider social background is created, which supports the e-sports industry, thus resembling what happens in the sport industry.

But similarities do not stop here. There is research which deals with reasons for intense sports watching and seeks a link with other activities that such a consumer of the sports industry prefers. A positive correlation was found between watching sports and playing video games. The link between sports spectating and video game playing appears to be symbiotic: since video game playing and watching TV and movies did not correlate, the relationship cannot be solely driven by media consumption. (Appelbaum, et al., 2011). 
Regarding preparations for a competition or training with teammates (e-sports competitions are mostly team centered types of competitions), there are certain parallels. When you're in a gaming house - especially when you have a manager and an analyst looking over your shoulder - nobody's mucking around. (Parkin, 2014).

A statistical analysis can be used as a concluding remark on the subject. The viewership is there: More fans (27 million worldwide) watched-online-the 2014 League of Legends (one of the e-sports games) world championship final between South Korea's Samsung Galaxy White team and China's Star Horn Royal Club than saw the clinching games of last year's World Series (23.5 million), NBA Finals (17.9 million) or Stanley Cup finals (six million) (Apstein, 2015).

\section{DISCUSSION AND RESULTS}

There are many opportunities to participate in the e-sports industry trend, and accordingly there are that many business plans and ways to monetize them. However, within the framework of the research, a conceptual business plan is required, one that will meet the long term needs of consumers (both the targeted ones and the potential ones), while at the same time creating conditions for the development of this phenomenon within the Croatian entertainment industry.

Following the development of the sports and e-sport industries in other countries, as well as the mentioned trends in organizing, participating and promoting such phenomena, there are a number of steps that an e-sports enthusiast could pursue with the goal of sustainable development of the e-sports industry and the earnings that are derived from an adequate approach to such activities. This set of steps, as showed in the Figure 1, represents the conceptual proposal of a business plan that should meet the needs of a growing number of e-sports enthusiasts, and ultimately result in mutual benefit and sustainable development.

Figure 1: Business Concept for E-sports
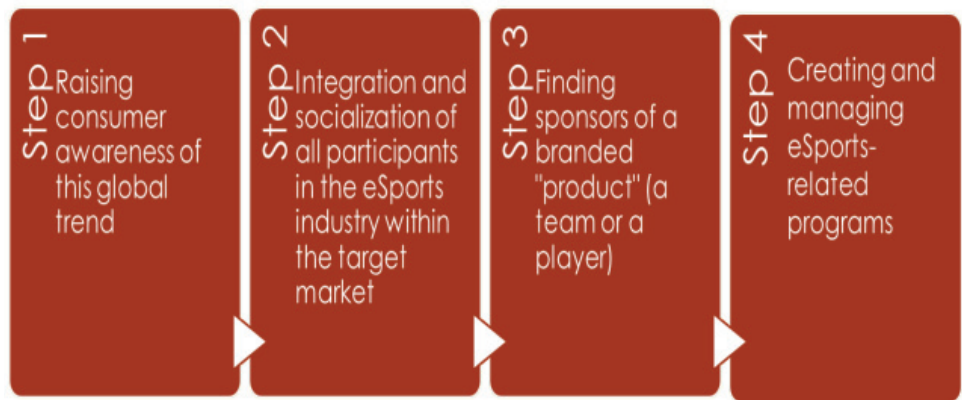

Source: Created by authors

To begin with, it is necessary to further promote the awareness and importance of the e-sports industry in increasing the quality of life, as well as the economic benefits 
of engaging in this trend. The organization of fairs, such as Reboot InfoGamer, held every year at the Zagreb Fair in November, as well as e-sports tournaments, should be a step in the right direction. The first step in our concept, therefore, refers to raising consumer awareness of this global trend.

Furthermore, as seen from the segmentation of the market, it is necessary to encourage and widen the e-sports community, more precisely all the enthusiasts already included in the e-sports trend in any form that is already explored in the research: players, viewers, other e-sports participants. One way to do this is to create a website with the appropriate content aimed at linking the supply of and demand for information, and bringing the e-sports phenomenon closer to a potential market that is not yet aware of the trend or has limited resources but a great desire and motivation to participate. One way of developing the community, especially applicable to Croatia, could be opening food/beverage serving facilities or civil associations with the theme of e-sports or video games belonging to e-sports. This would allow e-sports enthusiasts to have a place where they can gather information, share it and watch e-sports, or even organize something on their own. The second step of our concept is the integration and socialization of all participants in the e-sports industry within the target market.

Once an e-sports enthusiast base is established, and they no longer represent the potential but rather the target market, aware of their desires and needs, the next level of planning and implementation of e-sports industry-related business activities related to capitalization can take place. This means involving relevant Croatian companies with financial capabilities that can take over the organization of major events, as well as sponsor potential professional gaming candidates. By doing this, mutual branding (one could even say cobranding) and adding of value is being achieved. The third step of the proposed business plan/concept is to share the costs of organizing, managing and controlling a branded "product" - a competition, a team or a player. This step also includes creating additional value within the e-sports community.

Finally, there is also TwitchTv. The information about the value of Amazon's takeover of this streaming platform indicates the importance and value of the e-sports industry's consumer base. Instead of attempting to compete with the TwitchTv platform, which would probably be unsuccessful, an option might be to partner with that platform - more precisely to stream personal e-sports related content and to use already popular and proven successful monetization techniques in the form of subscriptions for access to additional content, as well as donations and digital marketing. The final step involves, but is not limited to, creating and managing e-sports-related programs, particularly focused on the target market, whose viewers, even though they certainly possess necessary English language skills needed to follow similar programs, would almost certainly prefer to follow news and players in their own native language. The first three steps as defined in the business plan/concept will make the last statement true. Finally, in order for this concept to be successful, an iterative application of the steps is recommended as long as the target market grows, or more precisely as long as there are economic and social reasons. 


\section{CONCLUSION}

The reviewed available literature answers most of the posed research questions. The reported statistics support the thesis of an increasing number of players within the e-sports industry, regardless of their recreational or professional status, as well as spectators, fans and other interest groups involved in creating value within the electronic sports industry. An e-sports average consumer profile has been identified, as well as what motivates him/her to partake in e-sports activities. It is necessary to emphasize the increasingly pronounced need for socialization and communication with other consumers and groups, as well as the growing intertwining of virtual reality and reality within the field of competitive video games. This intertwining is further emphasized by comparing it to sports, which, as a separate phenomenon, has long been present in everyday society, and is accepted as something that is worth investing in and monitoring.

As one of the directions for additional research, it would be useful to estimate the market potential of the e-sports industry on the territory of Croatia, a country that for various reasons still lags behind this trend. It would be also useful to conduct a survey of potential consumers' awareness regarding the concept of e-sports, with the aim of determining the factors causing the lag. Is this still a problem of inadequate technological predispositions caused by inadequate purchasing capabilities, or is the cause insufficient awareness? Is there a demand for e-sports related products and services, but the phenomenon remains underdeveloped due to an inadequate market offer?

Within the context of this research, it can be assumed that the answer to the latter question is positive - there is demand, but what is offered on the market is inadequate. The first real attempt to organize an e-sports event in this region occurred in January 2017 at the Zagreb Fair. The tournament was a two-day event featuring 4 e-sports games, with several professional players, but the tournament itself had no professional relevance and was organized as part of the Croatia Winter Music Festival (Večernji, 2017), probably due to cost savings, but also as a good experiment for future ventures in this field of entertainment.

Finally, there is the question of differentiating the terms sports and e-sports industry by consumers. While some strive to link these two concepts, others do not, while yet another group of people is not interested in the outcome of their discussion. It seems that consumers and stakeholders of this phenomenon are no longer concerned by the fact that e-sports is not officially accepted as a sport or a sports discipline, but they are only trying to extract from the similarity of the two terms/concepts some socially useful factors and to apply them to what they like and enjoy. It has to be noted that there is no particular need to look at e-sports as an area of disciplines that satisfy a traditional sport definition; we could just as well look at e-sports as a completely separate field of study. It allows us to borrow academic approaches and methodologies from traditional sport and training science and to apply them to what might be called "e-sports science" (Wagner, 2006). 


\section{REFERENCES:}

1. Appelbaum, L.G., et al. (2011) What is the identity of a sports spectator? Personality and Individual Differences 52 p.422-427

2. Apstein, S. (2015) E-sports nation: How competitive gaming became a flourishing sport. Sports Illustrated. Accessed: 13.3.2017. http://www.si.com/moresports/2015/10/29/esports-competitive-video-gaming

3. Borowy, M. (2008) Public Gaming: eSport and Event Marketing in the Experience Economy. University of British Columbia.

4. Eklund, L. (2014) Bridging the online/offline divide: The example of digital gaming. Computers in Human Behavior xx p.xxx-xxx

5. Entertainment Software Associaton (2015) Essential facts about the computer and video games industry. Accessed 13.3.2017. http://www.theesa.com/wp-content/uploads/2015/04/ESA-Essential-Facts-2015.pdf

6. Erzberger, T. (2016) The 2016 top 10 esports draft. Accessed 13.3.2017. http://www. espn.com/esports/story/_/id/16454680/the-2016-top-10-esports-draft

7. Esportsearnings (2017) Nikola "Niko" Kovač. Accessed: 13.3.2017. http://www.esportsearnings.com/players/5783-niko-nikola-kovac

8. Hamari,J. \& Sjöblom, M. (2016) Why do people watch others play video games? An empirical study on the motivations of Twitch users. Computers in Human Behavior. xxx p. $1-12$

9. Hamari,J. \& Sjöblom, M. (2017) What Is eSports and Why Do People Watch It? Internet research, 27(2). DOI: 10.1108/IntR-04-2016-0085, Forthcoming. Available at SSRN: https://ssrn.com/abstract=2686182

10. Jonasson, K. \& Thiborg, J. (2010) Electronic sport and its impact on future sport. Sport in Society Vol. 13, No. 2. p.287-299

11. Kim, E. (2014) Amazon buys Twitch for $\$ 970$ million in cash. Accessed 13.3.2017. http://www.businessinsider.com/amazon-buys-twitch-2014-8

12. Lang, D.J. (2016) In video games, spectating is the new advertising. Los Angeles. Accessed 13.3.2017. https://phys.org/news/2016-07-video-games-spectating-advertising.html

13. Marchand, A., Hennig-Thurau, T. (2013) Value Creation in the Video Game Industry: Industry Economics, Consumer Benefits, and Research Opportunities. Journal of Interactive Marketing 27 p.141-157

14. Martončik, M. (2015) e-Sports: Playing just for fun or playing to satisfy life goals? Computers in Human Behavior 48. p.208-211

15. Parkin, S. (2014) Boot camps build winners. New Scientist.

16. TwitchTv (2017) About. Accessed 13.3.2017. https://www.twitch.tv/p/about 
17. Večernji (2016) Zagreb Gaming Arena - veliki gaming događaj stiže u Zagreb. Accessed: 13.3.2017. http://www.vecernji.hr/croatia-winter-music-festival/zagreb-gaming-arena-veliki-gaming-dogadaj-stize-u-zagreb-1127788

18. Wagner, M.G. (2006) On the Scientific Relevance of eSports. Department for Interactive Media and Educational Technology, Krems, Austria.

19. Yee, N. (2006) Motivations for Play in Online Games. CYBERPSYCHOLOGY \& BEHAVIOR. Volume 9, Number 6. p.772-774

20. Zackariasson,P., Wilson T.L. (2010) Paradigm shifts in the video game industry. Competitiveness Review: An International Business Journal, Vol. 20 Iss: 2, p.139 - 151 


\title{
NOVI POSLOVNI MODEL U RASTUĆOJ E-SPORT INDUSTRIJI*
}

\author{
Anita Radman Peša ${ }^{7}$, Dijana Čičin-Šain ${ }^{8}$ \& Toni Blaževićc ${ }^{9}$
}

\begin{abstract}
Sažetak
E-sport, odnosno natjecateljsko igranje video igara, postaje rastućom industrijom te sve češćom temom raznih međunarodnih istraživanja. Svrha ovog istraživanja je smisliti novi, inovativni poslovni model na području e-sport industrije, koji će se moći primijeniti u obliku značajne poslovne prilike. Glavni ciljevi ovog rada uključuju određivanje ključnih sastavnica uspjeha e-sporta u rastućoj industriji video igara te prezentiranje nekih inovativnih načina upotrebe istih u vidu novih poslovnih prilika. Analizom pojma e-sport na nekoliko komponenti, analizira se njihova rentabilnost i mogućnost profitiranja većinom iz perspektive poduzetništva. Nadalje, određuje se segmentacija ciljnog tržišta e-sporta te se uspoređuje s tržištem tradicionalnog sporta, budući da se ta dva pojma trebaju promatrati zasebno, sudeći po raznim autorima.
\end{abstract} model.

Ključne riječi: E-sport industrija, tržište e-sporta, segmentacija tržišta, poslovni

\section{JEL klasifikacija: L82}

Rad je prezentiran na 2. Međunarodnoj konferenciji "Business \& Entrepreneurial Economics-BEE2017" koja je održana na Brijunima od 24. do 26. svibnja 2017. godine (www.bee-conference.com)

7 Dr. sc. Anita Radman Peša, docent, Sveučilište u Zadru, Odjel za ekonomiju, Zadar, Hrvatska, E-mail: apesa@unizd.hr

8 Dijana Čičin-Šain, mag. oec., viši predavač, Sveučilište u Zadru, Odjel za ekonomiju, Zadar, Hrvatska, E-mail: dcsain@unizd.hr

9 Toni Blažević, bacc. oec., Sveučilište u Zadru, Odjel za ekonomiju, Zadar, Hrvatska, E-mail: tblazevic@ student.unizd.hr 